Zeszyty Naukowe Szkoły Głównej Gospodarstwa Wiejskiego w Warszawie Problemy Rolnictwa Światowego tom 17 (XXXII), zeszyt 1, 2017: 116-124

DOI: $10.22630 /$ PRS.2017.17.1.11

Anna Nowak ${ }^{1}$

Uniwersytet Przyrodniczy w Lublinie

Tomasz Kijek ${ }^{2}$

Uniwersytet Marii Curie-Skłodowskiej w Lublinie

\title{
Wpływ wykształcenia kierownika na konkurencyjność gospodarstw rolnych
}

\section{Effect of the Education of the Manager on the Competitiveness of Farms}

\begin{abstract}
Synopsis. Niniejsze opracowanie jest próbą wypełnienia luki poznawczej w zakresie wpływu kapitału ludzkiego na konkurencyjność gospodarstw rolnych. Najbardziej mierzalną cechą kapitału ludzkiego jest wykształcenie, stąd też za cel niniejszego opracowania przyjęto ocenę wpływ poziomu wykształcenia kierownika na konkurencyjność towarowych gospodarstw rolnych. Badania zrealizowano na podstawie danych rachunkowych $\mathrm{z}$ towarowych gospodarstw rolnych uczestniczacych w Polskim FADN z lat 2010-2012. Wyniki badań wskazują na istnienie przewagi konkurencyjnej gospodarstw rolnych zarządzanych przez kierowników dysponujących wykształceniem wyższym względem podmiotów kierowanych przez rolników bez wykształcenia wyższego. Badania wykazały również przewagi konkurencyjne $\mathrm{w}$ zakresie produktywności ziemi, technicznego uzbrojenia ziemi i pracy $\mathrm{w}$ gospodarstwach rolnych $\mathrm{z}$ kierownikiem posiadającym wykształcenie rolnicze w porównaniu do tych, gdzie kierownik takiego wykształcenia nie posiadał.
\end{abstract}

Slowa kluczowe: konkurencyjność, gospodarstwa rolne, kapitał ludzki, poziom wykształcenia

\begin{abstract}
This paper is an attempt at filling the cognitive gap in the effect that human capital has on farms competitiveness. Education is the most measurable characteristic of human capital so the purpose of this paper is evaluating the effect of the manager's level of education on the competiveness of the commercial farms. The surveys were carried out based on accounting data provided by commodity farms participating in the Polish FADN in 2010-2012. The outcomes indicate a competitive advantage of farms run by managers who completed higher education over entities run by farmers without higher education. Surveys also demonstrated a competitive advantage to the extent of land productivity, equipment of land with technical facilities and labour on farms run by managers with higher education in comparison to farms whose managers had no such education.
\end{abstract}

Key words: competitiveness, farms, human capital, level of education

\section{Wprowadzenie}

Konkurencyjność stanowi przedmiot zainteresowania wielu teorii, od klasycznej i neoklasycznej po nową teorię wzrostu, czy nową teorię handlu. Aby można było kreować działania sprzyjające poprawie konkurencyjności, niezbędne jest jednak zdefiniowanie tego zjawiska oraz zidentyfikowanie podstawowych jego determinant $\mathrm{w}$ odniesieniu do

${ }^{1}$ dr inż., Katedra Ekonomii i Agrobiznesu, Uniwersytet Przyrodniczy w Lublinie, ul. Akademicka 13, 20-950 Lublin, e-mail: anna.nowak@up.lublin.pl

${ }^{2}$ dr, Katedra Zarządzania Jakością i Wiedzą, Uniwersytet Marii Curie-Skłodowskiej w Lublinie,

Pl. M. Curie-Skłodowskiej 5, 20-031 Lublin, e-mail: tomasz.kijek@poczta.umcs.lublin.pl 
badanych obiektów. Wielopłaszczyznowość konkurencyjności sprawia, że istnieje problem dotyczący wypracowania jednej uniwersalnej definicji oraz metody jej pomiaru. W niniejszym opracowaniu przyjęto, że konkurencyjność gospodarstw rolnych to „zdolność do skutecznego funkcjonowania (trwania) i rozwoju w warunkach istniejącej rywalizacji/konkurowania" (Kulawik i Wieliczko, 2012). Konkurencyjność pojedynczych przedsiębiorstw, w tym towarowych gospodarstw rolnych, wynika z efektów przewagi konkurencyjnej, której źródłem mogą być m.in. niższe koszty produkcji, wyższa jakość, czy też lepsza wydajność w porównaniu do konkurentów (Wellert, 1995). O konkurencyjności mikroekonomicznej decyduje jakość posiadanych przez przedsiębiorstwo zasobów oraz umiejętności zarządzających, dotyczące wykorzystania tych zasobów dla poprawy konkurencyjności podmiotu (Frączek, 2009). Centralne znaczenie w ocenie konkurencyjności w aspekcie mikroekonomii ma jednak efektywność ekonomiczna (Poczta i Siemiński, 2010).

Czynniki konkurencyjności gospodarstw rolnych pomimo, że były przedmiotem badań wielu autorów, nie zostały one jednak w sposób klarowny usystematyzowane. B. Dobiegała-Korona i S. Kasiewicz (2010) ujmują je w grupę czynników zewnętrznych i wewnętrznych względem badanego podmiotu, wyjaśniając to tym, że konkurencyjność przedsiębiorstwa na rynku jest efektem synergicznego oddziaływania wielu czynników wewnętrznych, tkwiących $\mathrm{w}$ przedsiębiorstwie oraz mechanizmów i uwarunkowań zewnętrznych istniejących w otoczeniu. Podobną klasyfikację czynników konkurencyjności gospodarstw rolnych proponuje L. Latruffe (2010), dzieląc je na determinanty kontrolowane przez gospodarstwo oraz determinanty pozostające poza kontrola gospodarstwa. T. Cebulak i in. (2008) wskazują, że zdolność konkurencyjna rolnictwa i poszczególnych jego podmiotów kształtowane są w większym stopniu przez zasoby wewnętrzne niż przez rynek. Nie należy jednak tylko im przypisywać roli kreatora przewagi konkurencyjnej, bowiem ich wykorzystanie zależy w znacznym stopniu od czynników zewnętrznych, które określają arenę konkurowania i jej przebieg.

Tabela 1. Wybrane badania z zakresu wpływu kapitału ludzkiego na funkcjonowanie gospodarstw rolnych

Table 1. Selected surveys concerning the effect of human capital on the operation of farms

\begin{tabular}{|c|c|}
\hline Autor i rok & Przedmiot badań \\
\hline Mathijs, Vranken (2000) & $\begin{array}{l}\text { Związek pomiędzy poziomem wykształcenia rolników a efektywnością } \\
\text { techniczną gospodarstw rolnych. }\end{array}$ \\
\hline $\begin{array}{l}\text { Gołębiewska, Klepacki } \\
\text { (2001) }\end{array}$ & $\begin{array}{l}\text { Wpływ wykształcenia rolników na sytuację ekonomiczną } 263 \text { gospodarstw, } \\
\text { które prowadziły zapisy rachunkowe dla potrzeb IERiGŻ. }\end{array}$ \\
\hline $\begin{array}{l}\text { Babuchowska, Marks- } \\
\text { Bielska (2015) }\end{array}$ & $\begin{array}{l}\text { Związek pomiędzy realizowaniem lub nierealizowaniem inwestycji a } \\
\text { wykształceniem rolników w } 74 \text { gospodarstwach mleczarskich z województwa } \\
\text { warmińsko-mazurskiego. }\end{array}$ \\
\hline Nowak, Kijek (2016) & $\begin{array}{l}\text { Wpływ poziomu wykształcenia kierowników gospodarstw rolnych na } \\
\text { produktywność pracy w towarowych gospodarstwach rolnych objętych } \\
\text { systemem FADN w czterech makroregionach rolniczych w Polsce. }\end{array}$ \\
\hline $\begin{array}{l}\text { Marcysiak, Marcysiak } \\
(2011)\end{array}$ & $\begin{array}{l}\text { Zakres oddziaływania cech jakościowych kapitału ludzkiego na wyniki } \\
\text { ekonomiczne gospodarstw. }\end{array}$ \\
\hline
\end{tabular}

Źródło: opracowanie własne na podstawie przeglądu literatury. 
Coraz większą rolę we wzroście konkurencyjności podmiotów rynkowych przypisuje się czynnikowi ludzkiemu. Kapitał ludzki jest nosicielem innowacyjności, a więc zarazem wszelkich przemian (Kołodziejczyk, 2002). Jest to efektem tego, że wraz z postępem technologicznym, podstawą działalności gospodarczej, również rolniczej, w coraz większym stopniu staje się wiedza oraz umiejętność korzystania z niej (Karwat-Woźniak i Chmieliński, 2006). Przewaga konkurencyjna gospodarstwa rolnego zależy zatem w dużej mierze od wiedzy, jaką dysponują rolnicy, gdyż nowoczesny sektor rolny jest w większym stopniu oparty na kapitale i informacji niż na pozostałych czynnikach produkcji (Coleman i in., 2004). Na znaczenie tego czynnika wskazują także D. Cho i Ch. Moon (2000), którzy uwzględniając model konkurencyjności Portera, podkreślają rolę kierowników podmiotów gospodarczych na wszystkich poziomach gospodarki. Badania dotyczące wpływu kapitału ludzkiego na funkcjonowanie gospodarstw rolnych podejmowane były $\mathrm{w}$ badaniach nielicznych autorów, zwykle dotyczyły one wpływu poziomu wykształcenia rolników na wybrane aspekty funkcjonowania gospodarstwa rolnego, np. wyniki produkcyjne, czy ekonomiczne. Przegląd wybranych badań z tego zakresu zamieszczono w tabeli 1.

Biorąc pod uwagę znaczenie kapitału ludzkiego w osiąganiu przewagi konkurencyjnej oraz fakt, że spośród cech określających kapitał ludzki najbardziej mierzalną cechą jest wykształcenie (Nowak i Kijek, 2016), za cel niniejszego opracowania przyjęto ocenę wpływu poziomu wykształcenia kierownika na konkurencyjność towarowych gospodarstw rolnych. Analizę przeprowadzono $\mathrm{w}$ dwóch wymiarach $-\mathrm{z}$ uwzględnieniem poziomu wykształcenia ogólnego (z podziałem na rolników posiadających wykształcenie wyższe oraz nie posiadających wykształcenia wyższego) producentów rolnych oraz wykształcenia rolniczego (z podziałem na rolników posiadających wykształcenie rolnicze oraz nie posiadających takiego wykształcenia). Warto podkreślić, że z uwagi na fakt niewielkiej liczby opracowań naukowych z zakresu roli poziomu wykształcenia producentów rolnych w rozwoju rolnictwa, niniejsze opracowanie wypełnia lukę poznawczą w tym zakresie i stanowi przyczynek do dalszych badań.

\section{Dane i metody}

Badania przeprowadzono na podstawie danych rachunkowych pochodzących z towarowych gospodarstw rolnych uczestniczących w Polskim FADN z lat 2010-2012. Jest to baza danych, w której dane zbierane są według jednolitych zasad, a gospodarstwa tworzą statystycznie reprezentatywną próbę towarowych gospodarstw rolnych funkcjonujących na obszarze UE. Dane te zostały udostępnione przez Instytut Ekonomiki Rolnictwa i Gospodarki Żywnościowej - Państwowy Instytut Badawczy w Warszawie. Liczebność gospodarstw rolnych przyjętych do analizy $\mathrm{z}$ podziałem na poziom wykształcenia kierowników przedstawiono w tabelach 2, 3 oraz 5 i 6 .

Do oceny konkurencyjności gospodarstw rolnych przyjęto następujące wskaźniki:

1) liczba pracujących na 100 ha UR $\left(\mathrm{AWU}^{3} / 100 \mathrm{ha}\right)$,

2) techniczne uzbrojenie ziemi - wartość środków trwałych na 1 ha UR (zł/ha),

3) techniczne uzbrojenie pracy - wartość środków trwałych przypadających na 1 AWU (zz/AWU),

\footnotetext{
${ }^{3} \mathrm{AWU}$ - osoba pełnozatrudniona w rolnictwie.
} 
4) produktywność ziemi - wartość produkcji rolniczej w przeliczeniu na 1 ha UR (zt/ha),

5) produktywność pracy - wartość dodana netto w przeliczeniu na 1 AWU (zł/AWU),

6) produktywność kapitału - wartość produkcji rolniczej w przeliczeniu na 1 zł wartości środków trwałych (zł).

W celu zbadania wpływu wykształcenia kierowników gospodarstw na konkurencyjność zarządzanych przez nich podmiotów, obliczono przewagi konkurencyjne dla poszczególnych grup gospodarstw jako relacje wskaźników uzyskanych przez gospodarstwa rolne z kierownikiem posiadającym wykształcenie wyższe do wskaźników osiaganych przez producentów bez wykształcenia wyższego. Podobne przewagi obliczono $\mathrm{w}$ odniesieniu do gospodarstw zarządzanych przez kierowników posiadających wykształcenie rolnicze oraz nie posiadających takiego wykształcenia.

\section{Wyniki badań}

W tabeli 2 oraz 3 przedstawiono liczebność badanych gospodarstw rolnych oraz wskaźniki ich konkurencyjności w zależności od poziomu wykształcenia kierownika gospodarstwa, z podziałem na wykształcenie wyższe (jedna grupa badawcza) oraz inne poza wyższym (druga grupa badawcza). Udział gospodarstw rolnych kierowanych przez rolników z wykształceniem wyższym wynosił 9,3\% w 2010 roku, 9,6\% w 2011 roku oraz $10,2 \%$ w 2012 roku.

Jak wynika $\mathrm{z}$ przeprowadzonych badań, $\mathrm{w}$ każdym $\mathrm{z}$ badanych lat wskaźnik uzbrojenia ziemi $\mathrm{w}$ pracę osiagał nieznacznie wyższy poziom $\mathrm{w}$ gospodarstwach kierowanych przez rolników nie posiadających wykształcenia wyższego. Przeciętnie w latach 2010-2012 na 100 ha użytków rolnych w pierwszej grupie gospodarstw pracowało 4,7 osób pełnozatrudnionych, podczas gdy $\mathrm{w}$ grupie drugiej 4,8 AWU. Techniczne uzbrojenie ziemi osiagało wyższy poziom w pierwszej grupie gospodarstw, przeciętna wartość tego wskaźnika w latach 2010-2012 wynosiła tu 15331,1 zł, przy 13660,2 zł w grupie gospodarstw zarządzanych przez kierownika bez wykształcenia wyższego. Podobną zależność można zauważyć w odniesieniu do technicznego uzbrojenia pracy. Wartość tego wskaźnika rosła w kolejnych latach w obu badanych grupach gospodarstw, jednak średni jego poziom był wyższy $w$ podmiotach kierowanych przez rolników posiadających wykształcenie wyższe. Istotną rolę $\mathrm{z}$ punktu widzenia oceny konkurencyjności gospodarstw rolnych odgrywa analiza produktywności. Wynika to $\mathrm{z}$ faktu, że zdolność do efektywnego wykorzystania czynników produkcji, przede wszystkim kapitału, technologii oraz ludzi stanowi miarę konkurencyjności (Kołodziejczak, 2010). Z badań wynika, że poziom wykształcenia kierownika determinował efektywność wykorzystania czynnika ziemi i pracy. Średnia wartość pierwszego z wymienionych wskaźników w latach 2010-2012 w pierwszej grupie gospodarstw wynosiła 6926,3 zł/ha, natomiast $\mathrm{w}$ grupie drugiej $6481,0 \mathrm{zł} / \mathrm{ha}$. Przeciętna produktywność pracy $\mathrm{w}$ badanym okresie osiagała 70920,4 zł/AWU oraz 59430,7 zł/AWU, odpowiednio w pierwszej i drugiej grupie badawczej. Produktywność kapitału wyrażonego wartością aktywów trwałych wynosiła średnio $\mathrm{w}$ badanych latach $0,45 \mathrm{zł} \mathrm{w}$ gospodarstwach zarządzanych przez kierowników $\mathrm{z}$ wykształceniem wyższym oraz $0,47 \mathrm{zł}$ w podmiotach, gdzie kierownik takiego wykształcenia nie posiadał. 
Tabela 2. Wskaźniki konkurencyjności oraz liczebność gospodarstw rolnych zarządzanych przez kierowników z wykształceniem wyższym

Table 2. The ratios of competitiveness and number of farms run by managers with higher education

\begin{tabular}{l|cccrr}
\hline \multicolumn{1}{c|}{$\begin{array}{c}\text { Liczebność próby oraz wskaźniki } \\
\text { konkurencyjności }\end{array}$} & $\begin{array}{c}\text { Jednostka } \\
\text { miary }\end{array}$ & 2010 & 2011 & 2012 & $2010-2012$ \\
\hline Liczebność próby & szt. & 1012 & 1028 & 1095 & 1045 \\
Pracujący na 100 ha UR & AWU/100 ha & 4,6 & 4,8 & 4,7 & 4,7 \\
Wartość środków trwałych na 1 ha UR & zł/ha & 13212,0 & 16012,7 & 16768,4 & 15331,1 \\
Wartość środków trwałych na 1 AWU & zł/AWU & 285065,9 & 331441,5 & 353638,1 & 323381,8 \\
Produktywność ziemi & zł/ha & 6117,5 & 7019,8 & 7641,5 & 6926,3 \\
Produktywność pracy & zł/AWU & 67355,3 & 70179,0 & 75226,9 & 70920,4 \\
Produktywność kapitału & zł & 0,46 & 0,44 & 0,46 & 0,45 \\
\hline
\end{tabular}

Źródło: opracowanie własne na podstawie danych Polskiego FADN.

Tabela 3. Wskaźniki konkurencyjności oraz liczebność gospodarstw rolnych zarządzanych przez kierowników bez wykształcenia wyższego

Table 3. The ratios of competitiveness and number of farms run by managers without higher education

\begin{tabular}{|c|c|c|c|c|c|}
\hline $\begin{array}{l}\text { Liczebność próby oraz wskaźniki } \\
\text { konkurencyjności }\end{array}$ & $\begin{array}{l}\text { Jednostka } \\
\text { miary }\end{array}$ & 2010 & 2011 & 2012 & 2010-2012 \\
\hline Liczebność próby & szt. & 9850 & 9706 & 9665 & 9740 \\
\hline Pracujący na 100 ha UR & AWU/100 ha & 4,9 & 4,9 & 4,7 & 4,8 \\
\hline $\begin{array}{l}\text { Wartość środków trwałych na } 1 \text { ha } \\
\text { UR }\end{array}$ & $\mathrm{zl} / \mathrm{ha}$ & 12281,3 & 14098,4 & 14600,8 & 13660,2 \\
\hline $\begin{array}{l}\text { Wartość środków trwałych na } 1 \\
\text { AWU }\end{array}$ & zł/AWU & 248922,9 & 288889,6 & 309484,2 & 282432,2 \\
\hline Produktywność ziemi & zł/ha & 5731,7 & 6496,7 & 7214,7 & 6481,0 \\
\hline Produktywność pracy & zł/AWU & 52946,8 & 59428,7 & 65916,6 & 59430,7 \\
\hline Produktywność kapitału & $\mathrm{zł}$ & 0,47 & 0,46 & 0,49 & 0,47 \\
\hline
\end{tabular}

Źródło: opracowanie własne na podstawie danych Polskiego FADN.

W tabeli 4 zaprezentowano wskaźniki przewag konkurencyjnych będacych relacją wskaźników obliczonych dla pierwszej i drugiej grupy gospodarstw. Wynika z niej, że w grupie gospodarstw kierowanych przez rolników z wykształceniem wyższym większość przyjętych do analizy wskaźników osiaga wyższą wartość niż w grupie drugiej. Techniczne uzbrojenie ziemi w latach 2010-2012 było o 12,2\% wyższe w pierwszej z badanych grup gospodarstw, natomiast techniczne uzbrojenie pracy osiagało tu $14,5 \%$ przewagę. Badania Floriańczyka i in. (2012) wskazują ponadto, że poziom wykształcenia rolników decyduje o dynamice procesów rozwojowych gospodarstw rolnych, a tym samym o reprodukcji majątku. Większej dynamice odtwarzania środków trwałych towarzyszył wzrost wykształcenia, a dodatkowo jego rolniczy profil. Produktywność ziemi w gospodarstwach rolników z wykształceniem wyższym była średnio w badanych latach blisko o 7\% wyższa niż w gospodarstwach rolników nie posiadających wykształcenia wyższego. Produktywność pracy osiagała $\mathrm{w}$ pierwszej z badanych grup gospodarstw prawie $20 \%$ przewagę względem grupy drugiej. W przypadku produktywności kapitału nieznacznie 
wyższe wskaźniki w badanym okresie osiagały gospodarstwa z drugiej grupy. Można to tłumaczyć tym, że gospodarstwa $\mathrm{z}$ kierownikiem posiadającym wykształcenie wyższe charakteryzowały się wyższym technicznym uzbrojeniem ziemi oraz pracy. Na problem niskiej obrotowości środków trwałych w gospodarstwach rolnych zwraca uwagę m.in. S. Mańko i R. Płonka (2010).

Tabela 4. Relacje wskaźników uzyskanych przez gospodarstwa rolne z kierownikiem posiadającym wykształcenie wyższe do tych, jakie osiągnęli rolnicy bez wykształcenia wyższego (kierownicy bez wykształcenia wyższego=100)

Table 4. Relations between ratios obtained by farms run by managers with higher education and those obtained by farmers without higher education (managers without higher education $=100$ )

\begin{tabular}{l|ccrr}
\hline \multicolumn{1}{c|}{ Wskaźnik przewagi konkurencyjnej } & 2010 & 2011 & 2012 & $2010-2012$ \\
\hline Pracujący na 100 ha UR & 93,9 & 99,0 & 100,5 & 97,8 \\
Wartość środków trwałych na 1 ha UR & 107,6 & 113,6 & 114,8 & 112,2 \\
Wartość środków trwałych na 1 AWU & 114,5 & 114,7 & 114,3 & 114,5 \\
Produktywność ziemi & 100,5 & 108,1 & 105,9 & 106,9 \\
Produktywność pracy & 127,2 & 118,1 & 114,1 & 119,3 \\
Produktywność kapitału & 99,2 & 95,1 & 92,2 & 95,5 \\
\hline
\end{tabular}

Źródło: opracowanie własne na podstawie danych z tabeli 2 i 3.

Kolejnym etapem badań była analiza wpływu wykształcenia rolniczego kierowników gospodarstw rolnych na konkurencyjność gospodarstw rolnych. Znaczenie wykształcenia rolniczego w odniesieniu do kierowników gospodarstw rolnych wiąże się nie tylko ze złożonością procesów produkcyjnych $\mathrm{w}$ rolnictwie, ale również $\mathrm{z}$ funkcjonowaniem na rynku unijnym oraz z możliwością korzystania z wielu instrumentów wspólnej polityki rolnej. W tabeli 5 oraz 6 przedstawiono liczebność badanych gospodarstw rolnych oraz wskaźniki ich konkurencyjności w zależności od tego, czy kierownik gospodarstwa dysponował wykształceniem rolniczym, czy też nie. Udział gospodarstw rolnych z kierownikiem posiadającym wykształcenie rolnicze wynosił 59,5\%,60,3\% oraz 60,4\%, odpowiednio w latach 2010, 2011 i 2012.

Tabela 5. Wskaźniki konkurencyjności oraz liczebność gospodarstw rolnych zarządzanych przez kierowników z wykształceniem rolniczym

Table 5. The ratios of competitiveness and number of farms run by managers with agricultural education

\begin{tabular}{l|cccrr}
\hline \multicolumn{1}{c|}{$\begin{array}{c}\text { Liczebność próby oraz wskaźniki } \\
\text { konkurencyjności }\end{array}$} & $\begin{array}{c}\text { Jednostka } \\
\text { miary }\end{array}$ & 2010 & 2011 & 2012 & $2010-2012$ \\
\hline Liczebność próby & szt. & 6463 & 6470 & 6502 & 6478 \\
Pracujący na 100 ha UR & AWU/100 ha & 5,3 & 5,4 & 5,3 & 5,3 \\
Wartość środków trwałych na 1 ha UR & zł/ha & 14711,6 & 17172,4 & 17742,7 & 16542,2 \\
Wartość środków trwałych na 1 AWU & zł/AWU & 276483,0 & 320037,0 & 335034,7 & 310518,2 \\
Produktywność ziemi & zł/ha & 6172,0 & 7083,7 & 7698,4 & 6984,7 \\
Produktywność pracy & zł/AWU & 55404,7 & 60721,5 & 63817,4 & 59981,2 \\
Produktywność kapitału & zł & 0,4 & 0,4 & 0,4 & 0,4 \\
\hline
\end{tabular}

Źródło: opracowanie własne na podstawie danych Polskiego FADN. 
Tabela 6. Wskaźniki konkurencyjności oraz liczebność gospodarstw rolnych zarządzanych przez kierowników bez wykształcenia rolniczego

Table 6. The ratios of competitiveness and number of farms run by managers without agricultural education

\begin{tabular}{l|cccrr}
\hline \multicolumn{1}{c|}{$\begin{array}{c}\text { Liczebność próby oraz wskaźniki } \\
\text { konkurencyjności }\end{array}$} & $\begin{array}{c}\text { Jednostka } \\
\text { miary }\end{array}$ & 2010 & 2011 & 2012 & $2010-2012$ \\
\hline Liczebność próby & szt. & 4399 & 4264 & 4258 & 4307 \\
Pracujący na 100 ha UR & AWU/100 ha & 4,5 & 4,4 & 4,2 & 4,4 \\
Wartość środków trwałych na 1 ha UR & zł/ha & 10212,5 & 11527,8 & 12094,6 & 11278,3 \\
Wartość środków trwałych na 1 AWU & zł/AWU & 225871,3 & 261411,4 & 288932,0 & 258738,3 \\
Produktywność ziemi & zł/ha & 5397,1 & 6034,8 & 6846,4 & 6092,8 \\
Produktywność pracy & zł/AWU & 53013,1 & 60091,3 & 70372,4 & 61158,9 \\
Produktywność kapitału & zł & 0,5 & 0,5 & 0,6 & 0,5 \\
\hline
\end{tabular}

Źródło: opracowanie własne na podstawie danych Polskiego FADN.

Z badań wynika, że w przypadku gospodarstw rolnych zarządzanych przez kierowników z wykształceniem rolniczym poziom uzbrojenia ziemi w pracę był wyższy niż w drugiej grupie badawczej. Przeciętnie w latach 2010-2012 na 100 ha UR pracowało 5,3 AWU w pierwszej grupie oraz 4,4 AWU w grupie drugiej. Rolnicy dysponujący kierunkowym wykształceniem rolniczym posiadali gospodarstwa charakteryzujące się relatywnie wyższym poziomem technicznego uzbrojenia ziemi oraz pracy. Pierwszy z wymienionych wskaźników osiagał w latach 2010-2012 wartość 16542,2 zt/ha w pierwszej oraz 11278,3 zł/ha w drugiej grupie gospodarstw rolnych. Natomiast wartość aktywów trwałych przypadających na 1 osobę pełnozatrudnioną w pierwszej grupie podmiotów przewyższała średnio w badanym okresie o 51780,0 zł wartość tego wskaźnika z drugiej grupy badawczej.

Tabela 7. Relacje wskaźników uzyskanych przez gospodarstwa rolne z kierownikiem posiadającym wykształcenie rolnicze do tych, jakie osiągnęli rolnicy bez wykształcenia rolniczego (kierownicy bez wykształcenia rolniczego=100)

Table 7. Relations between ratios obtained by farms run by managers with agricultural education and those obtained by farmers without agricultural education (managers without agricultural education $=100$ )

\begin{tabular}{l|cccr}
\hline \multicolumn{1}{c|}{ Wskaźnik przewagi konkurencyjnej } & 2010 & 2011 & 2012 & $2010-2012$ \\
\hline Pracujący na 100 ha UR & 117,7 & 121,7 & 126,5 & 121,8 \\
Wartość środków trwałych na 1 ha UR & 144,1 & 149,0 & 146,7 & 146,7 \\
Wartość środków trwałych na 1 AWU & 122,4 & 122,4 & 116,0 & 120,0 \\
Produktywność ziemi & 114,4 & 117,4 & 112,4 & 114,6 \\
Produktywność pracy & 104,5 & 101,0 & 90,7 & 98,1 \\
Produktywność kapitału & 79,4 & 78,8 & 76,7 & 78,2 \\
\hline
\end{tabular}

Źródło: opracowanie własne na podstawie danych z tabel 2 i 3

W gospodarstwach kierowanych przez producentów posiadających wykształcenie rolnicze osiaggano $\mathrm{w}$ każdym $\mathrm{z}$ badanych lat wyższy poziom produktywności ziemi. Wartość tego wskaźnika wyniosła tam w latach 2010-2012 blisko 7 tys. zł/ha, w grupie drugiej była prawie o 1 tys. zł niższa. Efektywność wykorzystania czynnika pracy w latach 2010 i 2011 również była wyższa w pierwszej grupie gospodarstw, natomiast w roku 2012 
przewagę osiagali rolnicy bez wykształcenia rolniczego. Inny wskaźnik (produktywność kapitału) był wyższy w gospodarstwach zarządzanych przez rolników bez wykształcenia rolniczego, co podobnie jak w przypadku grupy gospodarstw prowadzonych przez kierowników bez wykształcenia wyższego można wyjaśnić niższym poziomem technicznego uzbrojenia ziemi oraz pracy.

Wskaźniki przewag konkurencyjnych wskazują na wyższy poziom konkurencyjności tych podmiotów, które zarządzane były przez kierowników posiadających wykształcenie rolnicze. Przewaga $\mathrm{w}$ zakresie poziomu technicznego uzbrojenia ziemi $\mathrm{w}$ tych gospodarstwach wynosiła średnio $46,7 \%$, a w zakresie uzbrojenia technicznym pracy $20 \%$. Przeciętnie w latach 2010-2012 grupa ta osiagała także o 14,6\% wyższy poziom efektywności wykorzystania czynnika ziemi. W zakresie produktywności pracy przewaga ta w latach 2010 i 2011 była niższa - odpowiednio 4,5\% oraz 1\%, natomiast w roku 2011 wyższą produktywność uzyskiwali rolnicy w drugiej grupie badawczej. Efektywność wykorzystania kapitału wyrażona relacją wartości produkcji do wartości aktywów trwałych była o $11,8 \%$ wyższa $w$ gospodarstwach kierowanych przez rolników, którzy nie dysponowali wykształceniem rolniczym.

\section{Podsumowanie}

W opracowaniu dokonano oceny konkurencyjności badanych towarowych gospodarstw rolnych $\mathrm{w}$ Polsce $\mathrm{w}$ zależności od poziomu wykształcenia kierownika gospodarstwa. Przeprowadzone badanie stanowi zatem próbę wypełnienia luki poznawczej w zakresie wpływu kapitału ludzkiego na warunki i efekty gospodarowania. Wyniki badań wskazują, że poziom konkurencyjności w grupie gospodarstw zarządzanych przez kierowników dysponujących wykształceniem wyższym był większy niż w podmiotach kierowanych przez rolników bez wykształcenia wyższego. Większość przyjętych do badań wskaźników konkurencyjności wykazało również przewagę $\mathrm{w}$ gospodarstwach rolnych $\mathrm{z}$ kierownikiem posiadającym wykształcenie rolnicze względem podmiotów prowadzonych przez rolników bez wykształcenia specjalistycznego w tym zakresie.

Uzyskane wyniki wskazuja jednoznacznie na potrzebę podnoszenia kwalifikacji formalnych przez rolników. Wynika to z faktu, że źródeł przewagi konkurencyjnej upatruje się coraz częściej w niematerialnych zasobach przedsiębiorstwa. W warunkach gospodarki rynkowej znaczenie tego czynnika jest szczególne. Funkcjonowanie gospodarstw rolnych w coraz bardziej złożonym oraz zmiennym otoczeniu rynkowym wymaga bowiem od producentów nie tylko wiedzy specjalistycznej z zakresu rolnictwa, ale również wiedzy ekonomicznej, społecznej, umiejętności nawiązywania kontaktów z rynkiem, czy też skłonności do podnoszenie poziomu swojej wiedzy. Ludzie lepiej wykształceni nie tylko łatwiej akceptują zmieniające się warunki, ale też wykazują większą aktywność w zakresie poszukiwania i wdrażania nowych rozwiązań (Kołoszko-Chomentowska, 2008). Poprawa jakości kapitału ludzkiego może więc stanowić szansę wzrostu konkurencyjności gospodarstw rolnych, a w konsekwencji całego sektora rolnego. Z punktu widzenia polityki rolnej zasadnym wydaje się więc stworzenie odpowiednich warunków instytucjonalnych wspierających aktywność edukacyjną rolników, co ostatecznie powinno prowadzić do poprawy wyników ekonomicznych rolnictwa.

Dalsze prace w zakresie badania wpływu kapitału ludzkiego na konkurencyjność gospodarstwach rolnych powinny uwzględniać dodatkowe zmienne opisujące jakość 
zasobów ludzkich, np. doświadczenie rolników, czy posiadane przez nich umiejętności. Co więcej, zasadnym wydaje się badanie wpływu kapitału ludzkiego na konkurencyjność gospodarstw rolnych określaną przy pomocy syntetycznych mierników obejmujących większy zakres zmiennych cząstkowych. Ponadto, prowadzenie dalszych badań w oparciu o dane o charakterze przekrojowo-czasowym pozwoliłoby na uwzględnienie indywidualnej specyfiki poszczególnych obiektów oraz efektów okresowych.

\section{Literatura}

Babuchowska, K., Marks-Bielska, R. (2015). Rola czynnika ludzkiego w unowocześnianiu polskiego rolnictwa na przykładzie producentów mleka. Acta Universitatis Lodziensis, Folia Geographica Socio-Oeconomica, 20, $45-57$.

Cebulak, T., Firlej, K., Juchniewicz, M., Rowiński, J., Szczepaniak, I., Szymański, W., Wiatrak, A.P. (2008). Wybrane aspekty konkurencyjności polskich producentów żywności. Warszawa: IERiGŻ.

Cho, D., Moon, Ch. (2000). From Adam Smith to Michael Porter: Evolution to competitiveness theory. Singapore: World Scientific.

Coleman, W., Grant, W., Josling, T. (2004). Agriculture in New Global Economy. Cheltencham-Northampton: Edward Elgar.

Dobiegała-Korona, B., Kasiewicz, S. (2010). Metody oceny konkurencyjności przedsiębiorstw. W: K. Kuciński (red.) Uwarunkowania konkurencyjności przedsiębiorstw w Polsce. (s. 89-96). Materiały i Prace IFGN, t. LXXIX, Warszawa: Oficyna Wydawnicza SGH.

Floriańczyk,, Z., Janc, K., Czapiewski, K. (2012). The importance and diff usion of knowledge in the agricultural sector: the Polish experiences. Geographia Polonica, 85(1), 45-56.

Frączek, P. (2009). Determinanty konkurencyjności sektorów i przedsiębiorstw. Ujęcie teoretyczne. Przedsiębiorstwo i Region, 1, 7-16.

Gołębiewska, B., Klepacki, B. (2001). Wykształcenie rolników jako forma różnicująca sytuację gospodarstw rolniczych. Zeszyty Naukowe Uniwersytetu Rzeszowskiego, 7(42), 457-464.

Karwat-Woźniak, B., Chmieliński, P. (2006). Praca w indywidualnych gospodarstwach rolnych. Warszawa: IERiGŻ.

Kołodziejczak, A. (2010). Modele rolnictwa a zróżnicowanie przestrzenne sposobów gospodarowania w rolnictwie polskim. Poznań: Wydawnictwo Naukowe UAM.

Kołodziejczyk, D. (2002). Uwarunkowania społeczno-gospodarcze lokalnego rozwoju gospodarczego. Warszawa: IERiGŻ.

Kołoszko-Chomentowska, Z. (2008). Wykształcenie ludności rolniczej jako determinanta rozwoju rolnictwa. Zeszyty Naukowe SGGW - Ekonomika i Organizacja Gospodarki Żywnościowej, 67, 79-86.

Kulawik, J., Wieliczko, B. (2012). Wybrane finansowe aspekty konkurencyjności rolnictwa. Zagadnienia Ekonomiki Rolnej, 4, 36-53.

Latruffe, L. (2010). Competitiveness, Productivity and Efficiency in the Agricultural and Agri-Food Sectors OECD Food, Agriculture and Fisheries Papers, No. 30, OECD Publishing. Pobrane 15 grudnia 2016 z: http://dx.doi.org/10.1787/5km91nkdt6d6-en.

Mańko, S., Płonka, R. (2010). Struktura aktywów a wyniki działalności gospodarstw rolnych w świetle danych polskiego FADN. Zagadnienia Ekonomiki Rolnej, 4, 134-145.

Marcysiak, A., Marcysiak, A. (2011). Wpływ cech jakościowych kapitału ludzkiego na wyniki ekonomiczne gospodarstw rolniczych. Zeszyty Naukowe SGGW Problemy Rolnictwa Światowego, t. 11(26), z. 4, 129-137.

Mathijs, E, Vranken, L. (2000). Farm restructuring and efficiency in transition: Evidence from Bulgaria and Hungary. Selected Paper, American Agricultural Economics Association Annual Meeting, Tampa, Florida, 30 July -2 August 2000, 1-26.

Nowak, A., Kijek, T. (2016). The effect of human capital on labour productivity of farms in Poland. Studies in Agricultural Economics, 118, 16-21.

Poczta, W., Siemiński, P. (2010). Konkurencyjność rolnictwa polskiego po przystapieniu do Unii Europejskiej. Poznań: Wydawnictwo Uniwersytetu Przyrodniczego w Poznaniu.

Wellert, K. (1995). Zur Wettbewerbsfähigkeit von Molkerei- und Schlachtunternehmen im vereinten Deutschland. Göttingen: Cuvillier. 